\title{
KNOWLEDGE AND ATTITUDE TOWARDS PREMARITAL GENOTYPE SCREENING AMONG WOMEN OF CHILD-BEARING AGE IN KUMO AKKO LOCAL GOVERNMENT AREA OF GOMBE STATE
}

\author{
${ }^{* 1}$ Agofure, O. and ${ }^{2}$ Danzaria M. A.
}

\begin{abstract}
${ }^{*}$ Department of Public and Community Health, Novena University, Ogume, Delta State, Nigeria. Phone: +2347030839248 Email: agofureotovwe@yahoo.com

${ }^{2}$ Department of Public and Community Health, Novena University, Ogume, Delta State, Nigeria.

Phone: +2348025723061 Email: margareteawulo@gmail.com
\end{abstract}

\begin{abstract}
The prevalence of sickle cell anaemia has been shown to be on the increase in Nigeria. Therefore, preventive measures such as premarital genotype screening have been proposed as one of the ways of reducing the scourge of the disease. Therefore, this study was designed to assess the knowledge and attitude of women of child bearing age in Kuma Akko Local Government Area of Gombe State towards premarital genotype screening. The study adopted a descriptive cross-sectional design. A total of 296 respondents were sampled through simple random sampling technique and the collected data were analyzed using Statistical Package for the Social Sciences (SPSS) version 20.0. Majority of the respondents 200(71.40\%) were between the ages of 15-34 years old and 64(22.90\%) of the respondents affirmed that they had a family history of sickle cell disease. In addition, 58.60\% of the respondents demonstrated poor knowledge of premarital genotype screening while $57.10 \%$ exhibited negative perception towards premarital genotype screening and $63.20 \%$ exhibited poor attitude towards premarital genotype screening. There was a significant relationship between respondents with family history of sickle cell anaemia and their knowledge of premarital genotype screening. The study therefore recommends that efforts should be intensified by the governments and health workers in primary, secondary and tertiary level of healthcare deliveries, to raise awareness on the importance of premarital genotype screening in order to reduce the prevalence of Sickle cell anaemia in the locality.
\end{abstract}

Keywords: attitude, knowledge, perception, premarital genotype screening, sickle cell anaemia

LICENSE: This work by Open Journals Nigeria is licensed and published under the Creative Commons Attribution License 4.0 International License, which permits unrestricted use, distribution, and reproduction in any medium, provided this article is duly cited.

COPYRIGHT: The Author(s) completely retain the copyright of this published article.

OPEN ACCESS: The Author(s) approves that this article remains permanently online in the open access (OA) mode

QA: This Article is published in line with "COPE (Committee on Publication Ethics) and PIE (Publication Integrity \& Ethics)". 


\section{INTRODUCTION}

Genetic diseases which are hereditary in nature, are caused by abnormality in an individual's genome (AbioyeKuteyi, 2009; Austin, 2004). Sickle cell disease (SCD) a type of genetic disease and hereditary disorder characterized by red blood cell with abnormal form of haemoglobin called Hbs (Faremi et al., 2018). Sickle cell disease is as a result of the substitution of the amino acid glutamic acid with valine in the globin chain structure thereby altering the configuration of the whole protein molecule (Guyton and Hall, 1999; Faremi et al., 2018). Sickle cell disease is an autosomal recessive gene genetically transmitted hemoglobinopathy; responsible for considerable morbidity and mortality (Kamble and Chatrvedi, 2000). It is associated mainly with people whose ancestors came from sub-Saharan Africa, India, Saudi Arabia and the Mediterranean (Lawson, 2004). Nigeria by virtue of her large population has the greatest number of sufferers of SCD in the world with an estimated 24\% prevalence of sickle cell trait, 100,000 annual SCD births and 100,000 annual SCD infant deaths (Diwe et al., 2016; Federal Ministry of Health Nigeria, 2014; World Health Organization, 2006). In addition, a 10-year survey among children in South-Eastern Nigeria gave a prevalence of 5\% while a study in Benin, South-South Nigeria gave a prevalence of $3 \%$ (Adewoyin et al., 2015). Genetic screening uses a variety of laboratory procedures to find out if a person has a genetic condition or disorder or is likely to develop a disease based on his or her genetic makeup (Iweriebor, 2015). Premarital genetic testing can identify and modify behavioural, medical and other health risk factors known to impact pregnancy outcomes through prevention and management (Odelola et al., 2013).

\section{AIM OF THE STUDY}

To determine the knowledge and attitude of women of child bearing age towards premarital genotype screening for sickle cell anaemia.

\section{OBJECTIVES OF THE STUDY}

The study objectives were to:

1. to assess the knowledge of the respondents on premarital genotype screening

2. to determine the perception of the respondents towards premarital genotype screening

3. to determine the attitude of the respondents towards premarital genotype screening

\section{RESEARCH JUSTIFICATION}

Low levels of awareness and knowledge of premarital genotype screening has been a recurrent problem in Nigeria. For instance, a study carried out in Delta State showed that only $30 \%$ of the participants were knowledgeable of premarital genotype screening (Iweriebor, 2015). This is quite alarming and shows that despite the benefits of premarital genetic screening many in the population including intending couples might be ignorant of its benefits. In addition, in spite of current efforts to create awareness about premarital sickle cell counselling and screening; sickle cell diseases are still very common in our society especially in the northern part of the country because of consanguineous marriages. Therefore, this study was designed to investigate the knowledge of premarital genotype screening among women of child bearing age as premarital genotype screening remains one of the surest ways of preventing the occurrence of sickle cell disease in the population. 


\section{METHODOLOGY}

\section{STUDY DESIGN, AREA AND POLLUTION}

The study utilised a descriptive cross-sectional study. Women of children bearing age (15-49years), who reside in Kumo community of Akko LGA of Gombe state, were used for the study

\section{SAMPLE SIZE DETERMINATION}

Sample size was determined using single population proportion formula $n=Z^{2} p(1-p) / d^{2}$, with the following assumptions: prevalence (p) of 73.4\% from previous study (Ugwu, 2016), 95\% confidence level, 5\% margin of error; giving a sample size of 296.

\section{SAMPLING PROCEDURE}

Kumo town of Akko L.G.A. have eleven wards namely; Kumo Center,Kumo East,Kumo North,Garko Ward,Kalshingi Ward, Tukulma Ward, Tumu Ward, Pindiga Ward, Akko Ward, Kumo West and Kashere Ward. A two stage sampling method was used, the first stage involved randomly sampling of six out of the eleven wards by balloting which include; Kumo Center, Kumo North, Kalshingi Ward, Kashere Ward, Kumo West and Kumo East, out of the eleven wards in Kumo as mentioned above, while the second stage involved randomly administering the questionnaire to the respondents in those selected wards.

\section{INSTRUMENT FOR DATA COLLECTION}

A questionnaire was used for collection of the data. The questionnaire was structured into sections A-D. Section A comprised socio-demographic characteristics of the respondents; Section B comprised Knowledge of premarital screening for sickle cell anaemia, Section C Perception towards premarital genotype screening and Section D Attitude towards premarital genotype screening for sickle cell anaemia

\section{DATA ANALYSIS}

Completed copies of the questionnaire were retrieved and entered into the computer and analysed using the Statistical Package for the Social Sciences (SPSS) version 20.0. The data was presented in simple percentage, frequency distribution while Chi-Square and logistic regression were used to analyse variables of interest at $\mathrm{P}<0.05$. Knowledge of premarital genotype screening was measured on a 5-point scale graded; 0-2 poor knowledge of premarital genotype screening while $>2$ good knowledge of premarital genotype screening. In addition, Perception towards premarital genotype screening was measured on a 5-point scale graded; 0-2 negative perception towards premarital genotype screening while $>2$ positive perception towards premarital genotype screening. Furthermore, attitude towards premarital genotype screening was measured on an 8-point scale graded; 0-4 poor attitude towards premarital genotype screening while $>4$ good attitude towards premarital genotype screening.

\section{ETHICAL CONSIDERATION}

Ethical approval was sought from Akko L.G.A. The study followed the ethical principles guiding the use of human participants in research. 


\section{RESULTS}

Table 1: Socio-demographic characteristics of the respondents

\begin{tabular}{|c|c|c|c|}
\hline Variable & Frequency & Percentage & $\begin{array}{l}\text { Knowledge of Premarital } \\
\text { Genotype Screening }\end{array}$ \\
\hline \multicolumn{4}{|l|}{ Age } \\
\hline $15-34$ & 200 & 71.40 & \\
\hline $35-54$ & 75 & 26.80 & \\
\hline $55-74$ & 4 & 1.40 & \\
\hline $75-94$ & 1 & 0.40 & \\
\hline Total & 280 & $100 \%$ & \\
\hline \multicolumn{4}{|l|}{ Religion } \\
\hline Christian & 134 & 47.90 & \\
\hline Muslim & 96 & 34.30 & \\
\hline Others & 50 & 17.90 & \\
\hline Total & 280 & $100 \%$ & \\
\hline \multicolumn{4}{|c|}{ Marital Status } \\
\hline Single & 90 & 32.10 & 0.306 \\
\hline Married & 113 & 40.40 & \\
\hline Divorced & 26 & 9.30 & \\
\hline Widow & 51 & 18.20 & \\
\hline Total & 280 & $100 \%$ & \\
\hline \multicolumn{4}{|c|}{$\begin{array}{l}\text { If married how many } \\
\text { children }\end{array}$} \\
\hline $0-4$ & 114 & 55.70 & \\
\hline $5-9$ & 64 & 33.50 & \\
\hline $10-14$ & 10 & 5.20 & \\
\hline $15-19$ & 2 & 1.0 & \\
\hline $20-24$ & 1 & 0.50 & \\
\hline Total & 280 & $100 \%$ & \\
\hline \multicolumn{4}{|c|}{$\begin{array}{l}\text { Do you have any family } \\
\text { history of sickle cell disease? }\end{array}$} \\
\hline Yes & & & 0.00 \\
\hline No & 64 & 22.90 & \\
\hline Don't Know & 103 & 36.80 & \\
\hline \multirow[t]{2}{*}{ Total } & 113 & 40.40 & \\
\hline & 280 & $100 \%$ & \\
\hline
\end{tabular}

\section{KNOWLEDGE OF PREMARITAL GENOTYPE SCREENING}

Majority of the respondents 205(73.20\%) have heard of premarital genotype screening with hospital being their source of information. Furthermore, 87(42.40\%) of the respondents mentioned AA, AS, SS as type of genotype they know and majority 151(73.70\%) affirmed that patient with SS gene is said to be carrying the sickle cell genotype gene. In addition, only $48(28.70 \%)$ agreed that if they are preparing to get married, they will go for genotype screening test and $50(26.30 \%)$ affirmed that they did pre-genotype screening when preparing for marriage. 


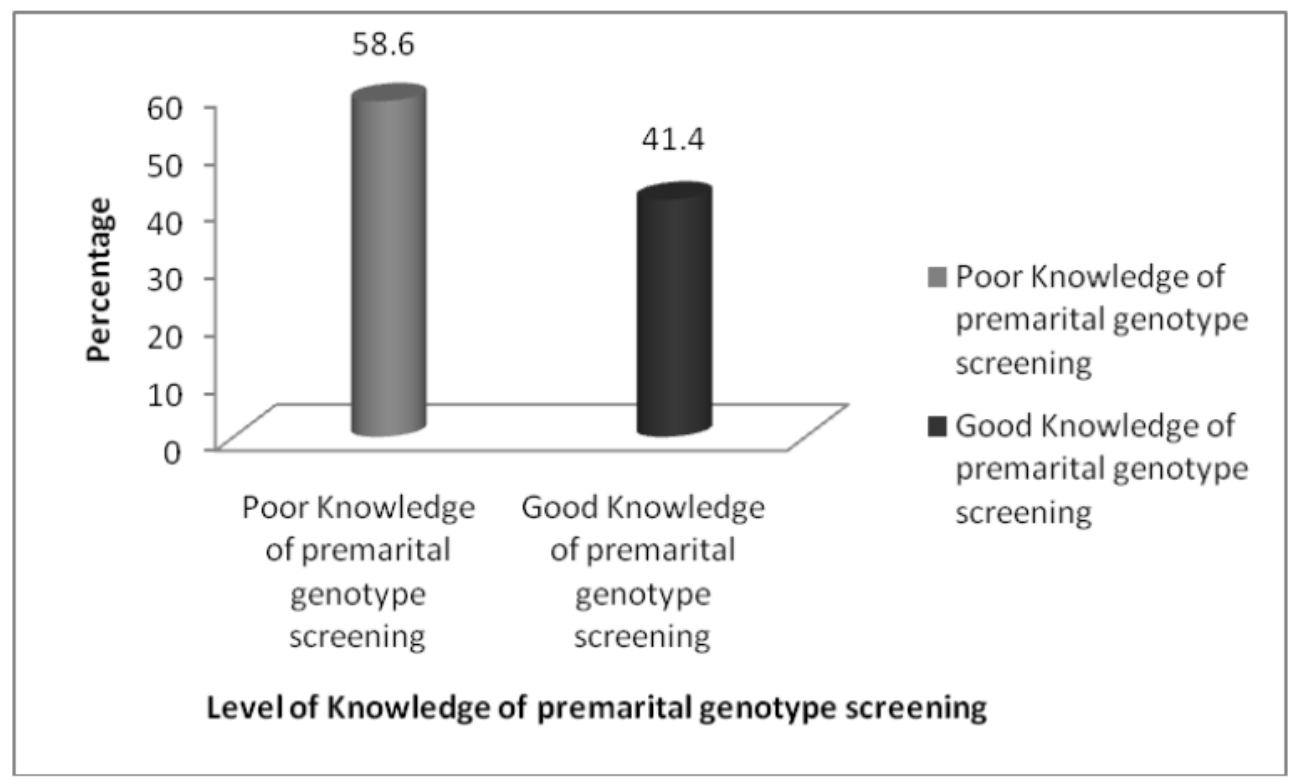

Figure 1: The level of knowledge of premarital genotype screening

\section{PERCEPTION TOWARDS PREMARITAL GENOTYPE SCREENING}

More than one third of the respondents $97(34.60 \%)$ agreed that premarital genotype screening is just a waste of time while 111(39.60\%) agreed that because of lack of trust of laboratory results they will not undergo premarital genotype screening and 62(22.10\%) strongly agreed that it is not advisable to do premarital genotype screening because one may lose the chance of getting married if one is having the sickle cell gene.

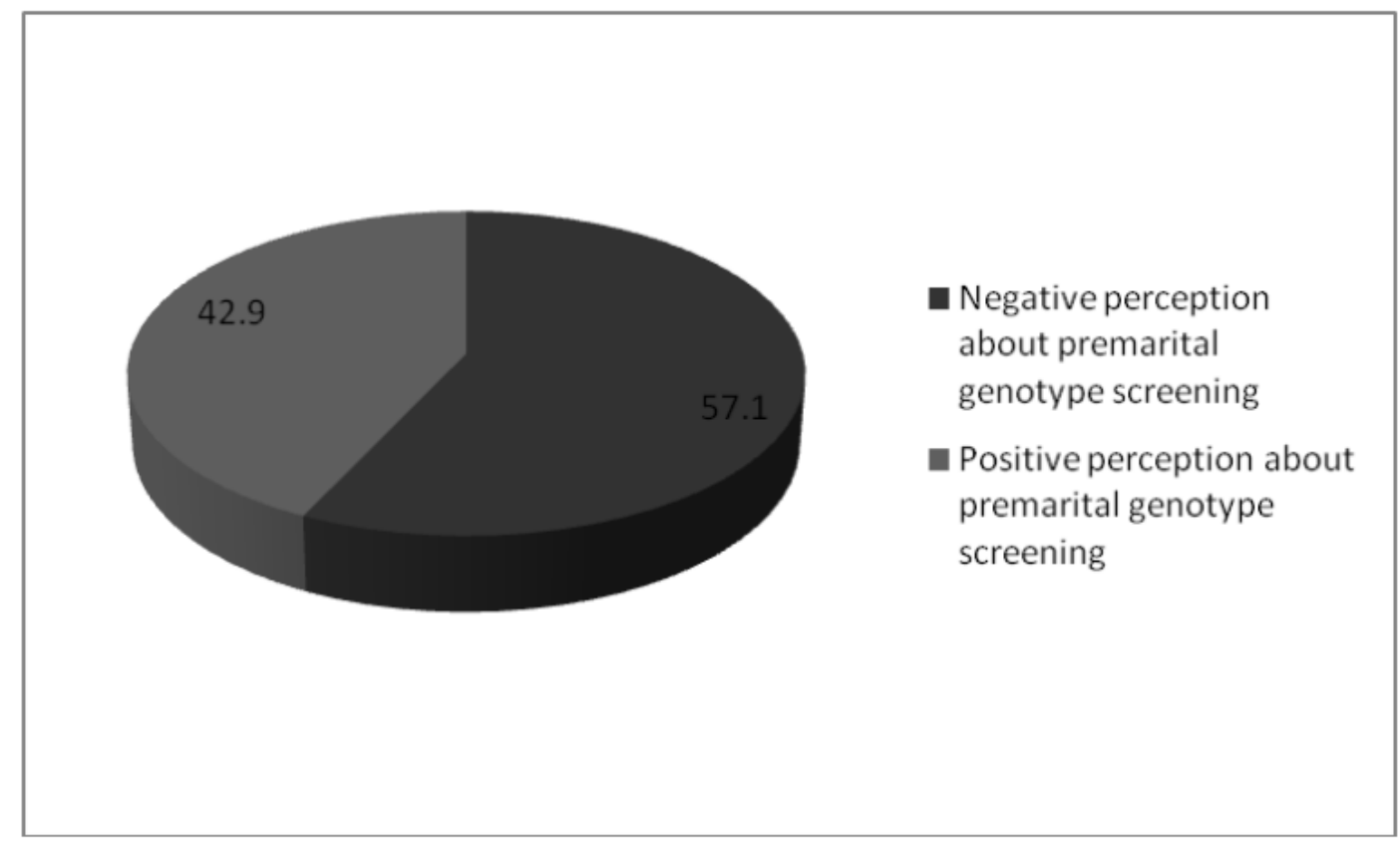

Figure 2: Level of perception towards premarital genotype screening 
Almost one third $85(30.40 \%)$ strongly agreed that premarital genotype screening is necessary once you agree to get married while $76(27.10 \%)$ agreed that the way to reduce this disease burden in a family is through premarital genotype screening and 60(21.40\%) strongly agree that it is mandatory to screen women of child bearing age before marriage. Furthermore, 55(19.60\%) agreed that they will be exposed if they go for sickle cell screening while $61(21.80 \%)$ agreed that premarital screening is not allowed in their culture and $79(28.20 \%)$ agreed that they will not do premarital genotype screening because if they have sickle cell gene no one will marry them.

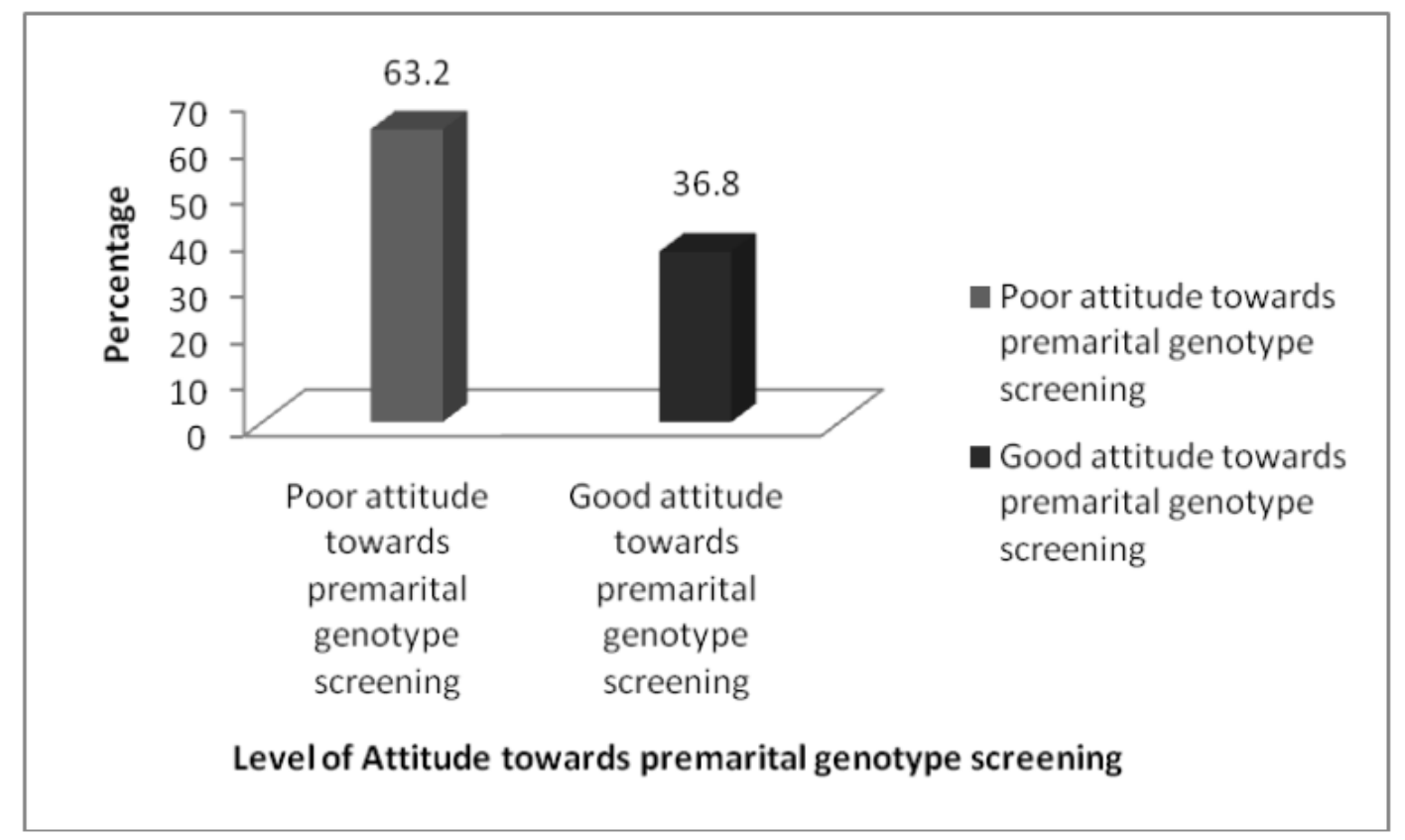

Figure 3: Level of attitude towards premarital genotype screening

\section{DISCUSSION}

The findings of the study show that majority of the respondents were between the ages of 15-34 years old while almost half were Christians and more than one third were married. In addition, some of the respondents affirmed that they had a family history of sickle cell disease. This finding is similar to a previous study were the respondents age group were between 16-36 years (Bazauye \& Olayemi 2009). This finding is not surprising as most women of reproductive age fall into this age group.

The findings of the study showed that most of the respondents were aware of premarital screening for sickle cell anaemia. This finding concur with previous studies were majority of the respondents were aware of sickle cell disease (Omuemu et al., 2013; Oyedele, 2015; Adewoyin et al., 2015). Furthermore, more of the respondents had hospital as their source of information of sickle cell screening. This is similar to previous study were the respondents had health personnel as their main source of information of sickle cell disease (Iweriebor, 2015). However, the finding was different from a previous study were the respondents affirmed school as their source of information of genetic disease (Oyedele, 2015).

In addition, only few agreed to go for genotype screening test before marriage. This finding is in contrast with previous study among youths where majority agreed to go for genotype screening (Oyedele, 2015). This shows that despite the awareness of the respondents of premarital genotype screening only few would want to go 
for the test. Thus, more awareness campaign on sickle cell anaemia among women of child bearing age should be regularly embarked upon especially in Northern Nigeria. In addition, since more of the respondents were married only few affirmed to do pre-genotype screening when preparing for their marriage. The results of the test showed that more of the respondents that did pre-genotype test had AS and are therefore carriers of the genetic gene. This finding was in contrast to the finding of a previous study were more of the respondents had AA (Oyedele, 2015).

In addition, the level of awareness of the respondents on premarital genotype screening did not translate to their knowledge of premarital genotype screening as more than half of the respondents $58.60 \%$ demonstrated poor knowledge of premarital genotype screening. This finding is similar to the findings of previous studies in Nigeria were the respondents demonstrated poor knowledge of premarital genotype testing (Iweriebor, 2015). The finding was however different from the findings of previous studies in Nigeria among youths were the respondents demonstrated good knowledge of sickle cell disease (Faremi, 2018; Oludarei and Ogili, 2013). Furthermore, there was a significant association of family history of sickle cell anaemia and knowledge of premarital genotype screening as respondents who had family history of the disease were 7 times more likely to have knowledge of premarital genotype screening than respondents who neither had or do not know if they had family history of sickle cell anaemia $(\mathrm{OR}=7.00795 \% \mathrm{CI}=3.540-13.872)$.

Furthermore, more than half of the respondents exhibited negative perception towards premarital genotype screening. This can be attributed to their poor knowledge of premarital genotype screening. Furthermore, most of the respondents believe premarital genotype screening is just a waste of time and lack of trust on laboratory results is why they would not undergo premarital genotype screening. This finding is similar to a previous study (Oyedele, 2015). This perception of premarital genotype screening among the respondents shows more enlightenment program on the importance of premarital genotype screening among intending couples should be embarked upon to increase the rate of screening among intending couples in Nigeria. Furthermore, there was a significant difference between the knowledge of premarital genotype screening and perception towards premarital genotype screening among the respondents. This poor perception of premarital genotype screening is similar to previous study (Al-Farsi et al., 2014).

In the same vein, there was a poor attitude towards premarital genotype screening among the respondents. This finding was contrary to the finding of a study in Ile-Ife and Lagos South-Western Nigeria were almost all of the respondents demonstrated good attitude towards premarital genotype screening (Abioye-Kuteyi, 2009; Oludarei and Ogili, 2013). This finding of the study could also be attributed to the poor knowledge and perception of premarital genotype screening by the respondents. Furthermore, there was a significant relationship between the knowledge of premarital genotype screening by the respondents and their attitude towards premarital genotype screening. Some of the respondents agreed and disagreed premarital genotype screening is necessary once you agree to marry while many disagree that premarital genotype screening is a sure way to reduce the burden of sickle cell disease.

Furthermore, some of the respondents believe they would be exposed if they go for sickle cell screening while some believes no one would agree to marry them if they are positive to sickle cell. This finding highlights the issue of stigmatization associated with the disease which can hinder screening. Therefore, more awareness and advocacies are needed in communities across Nigeria to sensitize the populace on the importance of premarital genotype screening. 


\section{RECOMMENDATIONS}

Based on the findings of the study the following recommendations were made:

1. There is need for intensive enlightenment campaign on premarital genotype screening before marriage especially among those with family history of the disease across communities in Nigeria as this would help in reducing the incidence of sickle cell disease.

2. Furthermore, the facilities for premarital genotype screening should be made accessible, affordable and available at all levels of health care delivery.

3. Government and non-governmental organization should work collaboratively to establish screening centers.

\section{LIMITATION OF THE STUDY}

In accessing the knowledge, perception and attitude towards premarital genotype screening, the study relied solely on the responses of the participants which could be subject to bias.

\section{CONCLUSION}

The respondents were aware of premarital genotype screening, however most demonstrated poor knowledge of premarital genotype screening. Furthermore, the respondents exhibited poor attitude and practices towards premarital genotype screening. This calls for urgent awareness and campaign in the study area to prevent the spread of the sickle cell gene in the community. 


\section{REFERENCES}

Abioye-Kuteyi, E. A., Oyegbade, O., Bello, I. and Osakwe C. (2009). Sickle cell knowledge, premarital screening and marital decisions among local government workers in Ile-Ife, Nigeria. African Journal of Primary Health Care \& Family Medicine, 1(1): 22- 25. doi :10.4102/phcf m.v1i1.2 2.

Adewoyin, A. S., Alagbe, A. E., Adedokun, B. O. and Idubor, N. T. (2015). Knowledge, Attitude and Control Practices of Sickle Cell Disease among Youth Corps Members in Benin City, Nigeria. Annals of Ibadan Postgraduate Medicine, 13(2): 100-107.

Al-Farsi, O. A., Al-Farsi, Y. M., Gupta, I., Ouhtit, A., Al-Farsi, K. S. and Al-Adawi, S. (2014).

A study on knowledge, attitude, and practice towards premarital carrier screening among adults attending primary healthcare centers in a region in Oman. BMC Public Health, 14: 380.

Austin, M. A., Hutter, C. M., Zimmern, R. L. and Humphries, S. E. (2004). Genetic Causes of

Monogenic Heterozygous Familial Hypercholesterolemia: A HuGE Prevalence Review. American Journal of Epidemiology, 160(5): 407-420, https://doi.org/10.1093/aje/kwh236

Bazauye, G. N. and Olayemi, E. E. (2009). Knowledge and Attitude of Senior Secondary

Schools Students in Benin City Nigeria to Sickle Cells Disease. World Journal of Medical Science, 4(1): $46-49$.

Diwe, K., Iwu, A. C., Uwakwe, K., Duru, C., Merenu, I., Ogunniyan, T., Oluoha, U., Ndukwu,

E. and Ohale, I. (2016). Prevalence and Patterns of Sickle Cell Disease among Children. Prevalence and Patterns of Sickle Cell Disease among Children Attending Tertiary and Non-Tertiary Health Care Institutions in a South Eastern State, Nigeria: A 10-year Survey. Journal of Research in Medical and Dental Science, 4(3).

Faremi, A. F., Olatubi, M. I. and Lawal, Y. R. (2018). Knowledge of Sickle Cell Disease and Pre Marital Genotype Screening among Students of a Tertiary Educational Institution in South Western Nigeria. International Journal of Caring Sciences, 11(1): 285.

Federal Ministry of Health Nigeria (2014). National Guideline for the control and management of Sickle cell disease 2014. Online at http://www.health.gov.ng/doc/SCDGuideline.pdf

Guyton, A. C. and Hall, J. E. (1999). Textbook of medical physiology.10th ed. London.W.B Saunders Company.

Iweriebor, O. B. (2015). Knowledge Attitude and Practice towards pre-maritial/prenatal genetic testing among young people (15-45) years of age in Sapele Local Government Area, Delta State, Nigeria. South American Journal of Academic Research, 2(1).

Kamble, M. and Chatruvedi, P. (2000). "Epidemiology of Sickle Cell Disease in a rural hospital of central India, Indian Paediatrics Journal, 37(4): 391-396

Lawson, J. B. (2004). Sickle cell disease in pregnancy. In O.B Stewar(Ed) Obstetrics and Gynaecology in the tropic and developing countries. London. Edward Amold publisher's Ltd.

Odelola, J. O., Adisa, O. and Akintaro, O. A. (2013). Attitude towards pre-marital genetic 
screening among students of Osun State Polytechnics in Nigeria. International Journal of Educational Administration and Policy Studies, 5(4): 53-58.

Oludarei, G. O. and Ogili, M. C. (2013). Knowledge, attitude and practice of premarital counseling for sickle cell disease among youth in Yaba, Nigeria. African Journal of Reproductive Health, 17(4): 175-82.

Omuemu, V. O., Obarisiagbon, O. E. and Ogboghodo, E. O. (2013). Awareness and acceptability of premarital screening of sickle cell disease among undergraduates of university of Benin, Benin City. Journal of biomedical sciences, 12(1): 91-1045.

Oyedele, E., Emmanuel, A., Gaji, L. D., and Ahure, D. E. (2015). Awareness and acceptance of premarital genotype screening among youth in a Nigerian community. International journal of medical and health research, 1(1): 17-21.

Ugwu, N. I. (2016). Pre-marital screening for sickle cell haemoglobin and genetic counselling:

awareness and acceptability among undergraduate students of a Nigerian University. International Journal of Medicine and Biomedical Research, 5(1).

World Health Organization (WHO) (2006). Sickle Cell disease prevention and control. Online at http://www.afro.who.int/en/nigeria/nigeria-publications/1775-sickle. 